\title{
Spectrophotometric Assay of some Nitrogen Containing Drugs in Pharmaceutical Formulations using p-Chloranilic Acid Reagent
}

\author{
Mahmood A. Hasan, Huda A. Ibrahim and Theia'a N. Al-Sabha \\ Department of Chemistry, Faculty of Science, University of Duhok, Iraq \\ Mahasan54@gmail.com \\ Department of Chemistry, Faculty of Science, University of Duhok, Iraq \\ Huda.mh81@yahoo.com \\ Department of Chemistry, College of Education, University of Mosul, Iraq \\ dr_theiaa@yahoo.co.uk
}

\begin{abstract}
A spectrophotometric method is developed for the determination of some drugs containing amino groups (sulfacetamide sodium, lidocaine and terbutaline sulfate) based on their reaction with $p$-chloranilic acid reagent in an organic medium forming colored charge transfer complexes. The complexes have maximum absorptions at 530 and 527 $\mathrm{nm}$ for sulfacetamide sodium and lidocaine respectively, but terbutaline sulfate gave two maximum absorptions at 529 and $319 \mathrm{~nm}$. Beers law is obeyed over the concentration range of $10-60 \mu \mathrm{g} \cdot \mathrm{ml}^{-1}$ for sulfacetamide sodium and lidocaine and 5$70 \mu \mathrm{g} \cdot \mathrm{ml}^{-1}$ for terbutaline sulfate. The molar absorptivity values are $0.940 \times 10^{3}, 0.913 \times 10^{3} \mathrm{~L} \cdot \mathrm{mol}^{-1} \cdot \mathrm{cm}^{-1}$ for sulfacetamide sodium and lidocaine respectively while terbutaline sulfate gave $0.987 \times 10^{3} \mathrm{~L}_{\mathrm{mol}}{ }^{-1} . \mathrm{cm}^{-1}$ at $529 \mathrm{~nm}$ and $7.407 \times 10^{3} \mathrm{~L}$. mol ${ }^{1} . \mathrm{cm}^{-1}$ at $319 \mathrm{~nm}$ with accuracy range between $100.20 \%$ and $101.42 \%$ and RSD better than $3.15 \%$ for all drugs. The method is applied successfully for determination of these drugs in pharmaceutical formulations and compared favorably with British Pharmacopeia standard methods. $F$ and $t$ tests are less than the tabulated values at $95 \%$ confidence level.
\end{abstract}

\section{Keywords}

Spectrophotometry; $p$-Chloranilic acid; Sulfacetamide sodium; Lidocaine; Terbutaline sulfate.

\section{Academic Discipline And Sub-Disciplines}

Analytical chemistry, Drugs, Charge transfer complexes, pharmaceutical formulations

\section{SUBJECT CLASSIFICATION}

Chemistry, Analytical chemistry

\section{TYPE (METHOD/APPROACH)}

Spectrophotometric determination of some drugs

\section{Council for Innovative Research}

\author{
Peer Review Research Publishing System
}

\section{Journal: Journal of Advances in Chemistry}

Vol. 9, No. 1 


\section{Introduction}

Sulfa drugs are among the first pharmaceutical agents used in veterinary practice. These drugs are widely used in the treatment of infections, especially for patients intolerant to other antibiotics [1,2] Sulfacetamide (I) is active against Gram positive bacteria, Gram negative bacteria, Chlamydia and Mode of resistance [3].

Terbutaline sulfate (II) is widely used as a prophylactic drug as well as to prevent acute exacerbations of asthma, chronic bronchitis, emphysema and other lung diseases. It relaxes muscles and opens air passage in the lungs, making them easier to breathe [4,5]. It is a short-acting bronchorelaxant which can be given orally [6]. It is readily metabolized in the gut wall and liver when given orally. It has a short duration of action [7].

Lidocaine (III) is a common local anesthetic [8] and antiarrhythmic drug used to treat burning and pain from skin inflammations. Lidocaine patches are used to relieve the pain of post-herpetic neuralgia (the burning, stabbing pains or aches that may last for months or years after a shingles infection) [9].

Viscous lidocaine is used to relieve pain and discomfort from a sore throat/mouth. It is also used to numb the lining of the mouth and throat before certain medical/dental procedures (e.g., dental impressions) [10].

Different analytical techniques have been described for determination of sulfacetamide sodium, lidocaine and terbutaline sulfate, such as HPLC [11-13], voltammetry [14-16], GC [17,18] and Spectrofluorimetry [19]. These methods are often time-consuming, expensive, and cumbersome. Spectrophotometry continues to be very popular, because of its simplicity, versatility and low cost. Several spectrophotometric methods using different reagents have been reported for determination of sulfacetamide sodium, lidocaine and terbutaline sulfate. Diazotization coupling method using 8 hydroxyquinoline [20], iminodibenzyl [21], Phloroglucinol [22] and 3-Aminophenol [23] as coupling agents for determination of sulfacetamide. 4-Aminoantipyrine in the presence of potassium ferricyanaide [24], Fe (III) in the presence of potassium ferricyanide [25] and sodium periodate in the presence of acetylacetone [26] are used for determination of terbutaline sulfate. Phenol red or chlorophenol red [27], Bromocresol purple [28] and Sodium nitroprusside in the presence of hydroxylamine [29] are used for determination of lidocaine.

The present method is based on the charge transfer complex formation reaction of above drugs as $n$-donors with $p$ chloranilic acid as $\pi$-acceptor without any derivatization or catalysis.<smiles>CNN(C(C)=O)S(=O)(=O)c1ccc(N)cc1</smiles>

Sulfacetamide sodium

$\mathrm{M} \cdot \mathrm{Wt}=254.24 \mathrm{~g} \cdot \mathrm{mol}^{-1}$<smiles>CC(C)(C)NCC(O)c1cc(O)cc(O)c1</smiles>

Terbutaline sulfate

$\mathrm{M} . \mathrm{Wt}=548.7 \mathrm{~g} \cdot \mathrm{mol}^{-1}$<smiles>CCN(CC)CC(=O)Nc1c(C)cccc1C</smiles>

Lidocaine

$\mathrm{M} \cdot \mathrm{Wt}=548.7 \mathrm{~g} \cdot \mathrm{mol}^{-1}$

\section{Experimental}

\section{Apparatus}

All spectral absorption measurements are made on a Jenway 6800 U.V- visible double beam and 6305 U.V-visible single beam spectrophotometers, with $1-\mathrm{cm}$ matched quartz cuvettes. Heating of solutions is carried out on a water bath (SWBD) product by Bio Cote Company. Weighing is carried out on a sensitive balance type of DENVER balance Tp-214 with four digitals.

\section{Reagents}

All chemicals used are of analytical or pharmaceutical grade.

p-Chloranilic acid ( $p$-CA) reagent (Fluka) $\left(1 \times 10^{-3}\right.$ M) Solution: It is prepared by dissolving $0.0209 \mathrm{~g}$ of 2,5 -dichloro3,6 -dihydroxy-1,4-p-benzoquinone ( $p$-CA) in absolute ethanol $(99.9 \%)$ in $100 \mathrm{ml}$ volumetric flask. The solution is prepared daily and used immediately.

\section{Standard solutions of pure forms drugs $\left(250 \mu \mathrm{g} \cdot \mathrm{mr}^{-1}\right)(\mathrm{SDI}$, Sammara-Iraq)}

A $0.025 \mathrm{~g}$ of sulfacetamide sodium and lidocaine are dissolved separately in ethanol and terbutaline sulfate dissolved in $10 \mathrm{ml}$ methanol. The volumes were completed to $100 \mathrm{ml}$ with absolute ethanol. These solutions are prepared daily and used immediately.

\section{Sulfacetamide sodium eye drops (100 mg/ml)/ (Amman pharmaceutical industries, Jordan)}

A volume of $0.5 \mathrm{ml}$ of $100 \mathrm{mg} \cdot \mathrm{ml}^{-1}$ sulfacetamide is diluted by absolute ethanol to $50 \mathrm{ml}$ in a volumetric flask and filtrated through Whattman filter paper no.4 containing anhydrous sodium sulfate to remove the water content, then $12.5 \mathrm{~m}$ portion from the filtrate is diluted to $50 \mathrm{ml}$ by absolute ethanol, and this gave a solution containing $250 \mu \mathrm{g} . \mathrm{ml}^{-1}$ sulfacetamide sodium. 


\section{Lidocaine gel (2\% w/w)/ (Sina-Darou Tehran-Iran)}

An amount equivalent to $5.0 \mathrm{~g}$ of lidocaine hydrochloride gel is weighed accurately and dissolved in $5 \mathrm{ml}$ of $36 \%$ hydrochloric acid and heated in water bath for $10 \mathrm{~min}$ to increase the solubility, then allowed to cool and transferred to a $250 \mathrm{ml}$ separating funnel. $20 \mathrm{ml}$ distilled water was added followed by addition of $5 \mathrm{M}$ sodium hydroxide until the solution became alkaline ${ }^{[12]}$, then extraction with three portions of $10 \mathrm{ml}$ chloroform is performed. The chloroform extracts filtered through $2 \mathrm{~g}$ anhydrous sodium sulphate and the filtrate is completed to $100 \mathrm{ml}$ by absolute ethanol; a solution containing $1000 \mu \mathrm{g} . \mathrm{ml}-1$ lidocaine has been obtained. From this solution $12.5 \mathrm{ml}$ was taken and diluted to $50 \mathrm{ml}$ by absolute ethanol, the final concentration was $250 \mu \mathrm{g} \cdot \mathrm{ml}^{-1}$ lidocaine.

\section{Terbutaline sulfate tablets $(5 \mathrm{mg})$ / (Mediotic Labs, Homs - Syria)}

An accurately weighed portion of the powder equivalent to $0.025 \mathrm{~g}$ terbutaline sulfate is dissolved in $20 \mathrm{ml}$ methanol, heating with stirrer to increase the solubility, filtered into $50 \mathrm{ml}$ volumetric flask completed to the volume with absolute ethanol (the solution was equivalent to $500 \mu \mathrm{g}_{\mathrm{m} \mathrm{l}^{-1}}$ terbutaline sulfate). From this solution a $250 \mu \mathrm{g} \cdot \mathrm{ml}^{-1}$ terbutaline sulfate solution was prepared

\section{General procedure}

An increased volumes of $250 \mu \mathrm{g} \cdot \mathrm{ml}^{-1}$ working solutions of sulfacetamide sodium, lidocaine and terbutaline sulfate were transferred to a series of $5 \mathrm{ml}$ volumetric flasks to cover the concentration range $10-60 \mu \mathrm{g} \cdot \mathrm{ml}^{-1}$ for sulfacetamide sodium and lidocaine and $5-70 \mu \mathrm{g} \cdot \mathrm{ml}^{-1}$ for terbutaline sulfate solutions, followed by the addition of $1.4,1.6$, and $0.8 \mathrm{ml}$ of $1 \times 10$ ${ }^{3} \mathrm{M}$ of $p$-CA respectively, diluted to the mark with absolute ethanol and the absorbance was measured at 530 and $527 \mathrm{~nm}$ for sulfacetamide sodium and lidocaine respectively and terbutaline sulfate was measured at 529 and $319 \mathrm{~nm}$ against their respective blank after $5 \mathrm{~min}$ at room temperature.

\section{Results and Discussion}

\section{Absorption spectra}

The spectrum of $p$-CA, as m-acceptor, in absolute ethanol exhibits an absorption band at $460 \mathrm{~nm}$. The addition of sulfacetamide sodium, lidocaine or terbutaline sulfate, as $n$-donors, to this solution cause an immediate shift with new characteristic bands at $530 \mathrm{~nm}$ for sulfacetamide, $527 \mathrm{~nm}$ for lidocaine where as terbutaline shows two absorption bands at 529 and $319 \mathrm{~nm}$ when measured against their respective blank (Fig.1). These bands may be attributed to the formation of $p$-CA radical anions and the band at $319 \mathrm{~nm}$ may be attributed to the interaction of $p$-CA with the hydroxyl group present in terbutaline forming $n-\pi$ charge transfer complex.

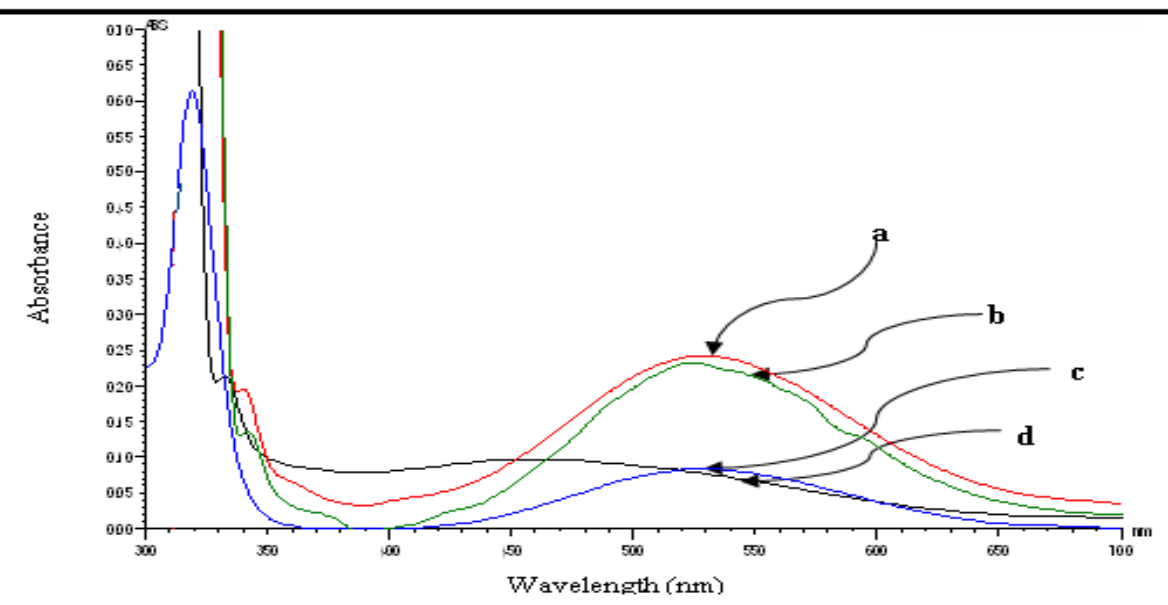

Fig. 1: Absorption spectra of a) $50 \mu \mathrm{g} \cdot \mathrm{ml}^{-1}$ sulfacetamide sodium versus blank, b) $50 \mu \mathrm{g} \cdot \mathrm{ml}^{-1}$ lidocaine versus blank, c) $60 \mu \mathrm{g} \cdot \mathrm{ml}^{-1}$ terbutaline sulfate versus blank and d) reagent blank versus ethanol.

\section{Optimization of conditions}

\section{Effect of solvent}

It was observed that $\mathrm{p}-\mathrm{CA}$ react with water (electron-rich agent) to form charge-transfer complex giving a violet colored product according to the following mechanism, scheme (1) [30]: 
<smiles>CC(C)(O)C1(C)C(=O)C(Cl)=C(O)C(=O)C1(C)O</smiles>

Scheme 1: Reaction of water with $p$-CA

Therefore water was canceled in all the subsequent experiments in this work. Different organic solvents like methanol, ethanol, acetone, acetonitrile, propanol and butanol are examined. It was observed that using absolute ethanol, as solvent for both $p-C A$ and drugs and also for dilution, gave maximum absorbance intensity at respective $\lambda_{\text {max }}$ Therefore; this solvent was used in all subsequent experiments.

\section{Effect of temperature and developing time}

The effect of temperature on the rate of reaction between $p$-CA and drugs is studied by mixing of $1 \mathrm{ml}$ of each sulfacetamide sodium, lidocaine and terbutaline sulfate respectively and separately with $1 \mathrm{ml}$ of $1 \times 10^{-3} \mathrm{M} \mathrm{p}$-CA in $5 \mathrm{ml}$ volumetric flasks. The results indicate that complexes are formed after addition of reagent immediately at room temperature $\left(25^{\circ} \mathrm{C}\right)$. The complexes remain constant for more than $24 \mathrm{hr}$. However, 5 minutes as developing time is recommended in subsequent experiments.

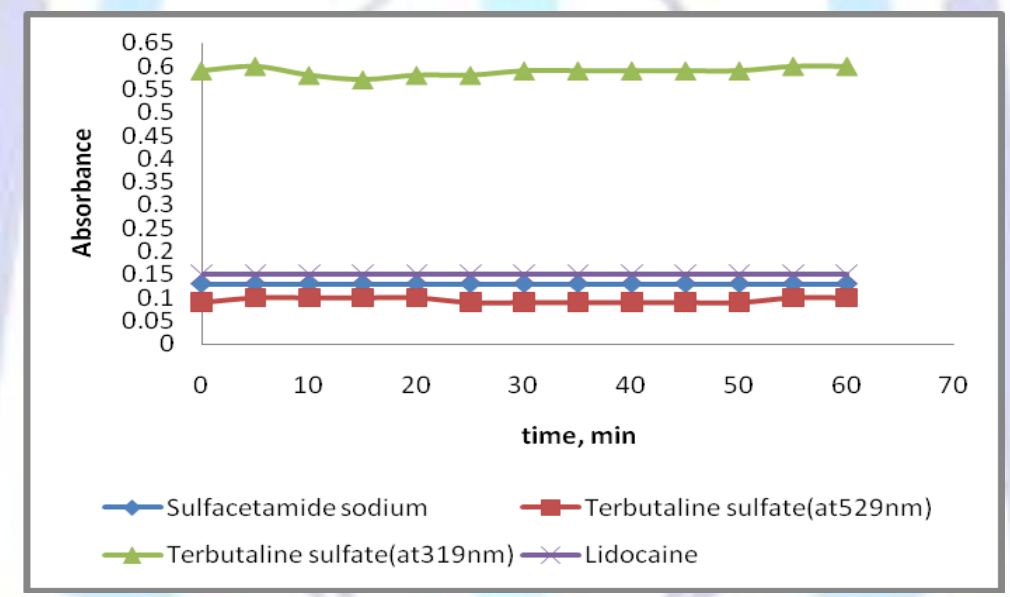

Fig.2: Effect of time on the absorbance of drug-p-CA complexes

\section{Effect of p-CA reagent concentration}

The effects of changing the volume of $1 \times 10^{-3} \mathrm{M} \mathrm{p}$-CA is studied over the range of $0.0-2.0 \mathrm{ml}$ in a solution containing $50 \mu \mathrm{g} \cdot \mathrm{ml}^{-1}$ sulfacetamide sodium, terbutaline sulfate and lidocaine. The results, as shown in Fig. 3 , reveal the fact that $1.4,0.8$ and $1.6 \mathrm{ml}$ of $p-\mathrm{CA}$ respectively is required to achieve the maximum intensity of the color in final dilution with ethanol.

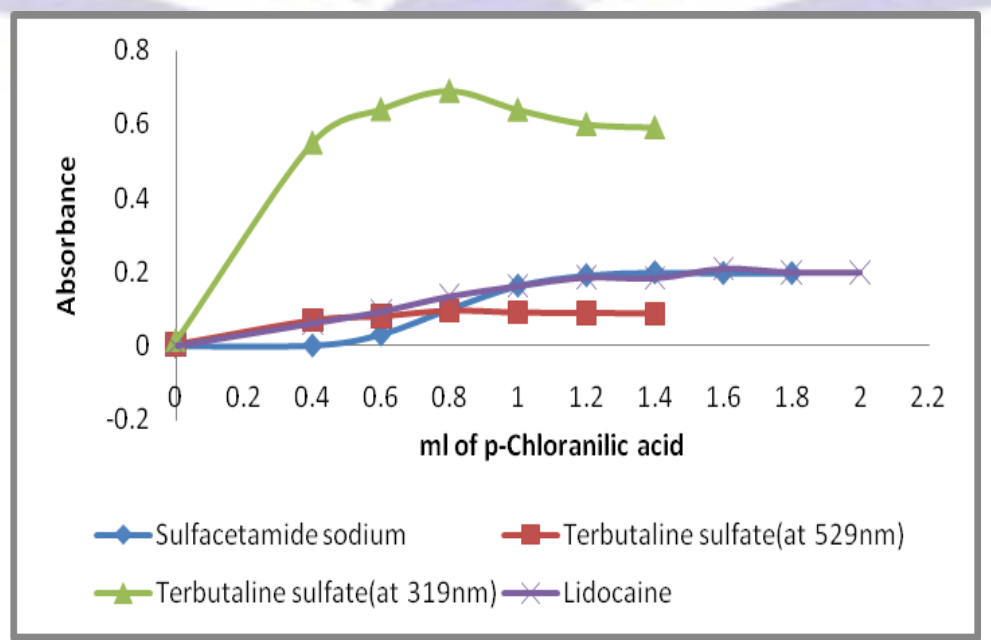

Fig.3: Effect of $p$-CA reagent on the absorbance of drug complexes 


\section{Effect of surfactants}

The effect of various surfactants including SDS, CTAB, Tween- 80 and Triton $x-100$, of $0.1 \%$ concentration, on the absorption intensity of the $p$-CA-drugs complexes are investigated. Tween-80 has no effect on the absorbance, other surfactants have negative effects.

However; the optimum conditions for the reaction of $p-C A$ with the intended drugs are summarized in Table (1).

Table (1): Optimum reaction conditions for the determination of drugs

\begin{tabular}{|c|c|c|c|c|c|c|}
\hline Compound & $\begin{array}{l}\lambda_{\max } \\
(\mathrm{nm})\end{array}$ & Temp. & $\begin{array}{c}p-C A \\
1 \times 10^{-3} \mathrm{M} \\
(\mathrm{ml})\end{array}$ & $\begin{array}{c}\text { Development } \\
\text { time } \\
\text { (min.) }\end{array}$ & $\begin{array}{c}\text { Stability } \\
\text { period } \\
\text { (min.) }\end{array}$ & $\begin{array}{c}\text { Final } \\
\mathrm{pH}\end{array}$ \\
\hline $\begin{array}{l}\text { Sulfacetamide } \\
\text { sodium }\end{array}$ & 530 & R. $T^{*}$ & 1.4 & 5 & 60 & 3.65 \\
\hline Lidocaine & 527 & R.T & 1.6 & 5 & 60 & 4.02 \\
\hline \multirow{2}{*}{ Terbutaline sulfate } & 529 & \multirow{2}{*}{ R.T } & \multirow{2}{*}{0.8} & \multirow{2}{*}{5} & \multirow{2}{*}{60} & \multirow{2}{*}{2.68} \\
\hline & 319 & & & & & \\
\hline
\end{tabular}

${ }^{*} \mathrm{R} . \mathrm{T}=$ Room temperature $\left(25^{\circ} \mathrm{C}\right)$

\section{Quantitation}

In order to investigate the range in which the colored complexes adhere to Beer's law, the absorbance of the complexes were measured at their corresponding $\lambda_{\max }$ value after developing the color by following the general procedure for individual calibrations for a series of solutions containing increasing amounts of each drug (Figure 4). The Beer's law limits, molar absorptivity and Sandell's sensitivity values were evaluated and given in Table 2 . The linearity was represented by the regression equation and the corresponding correlation coefficient for the studied determined drugs by the proposed method represents excellent linearity. The relative standard deviation (RSD) and accuracy (average recovery \%) for the analysis of four replicates of each three different concentrations for each drug indicated that the method is precise and accurate. Limit of detection (LOD) and limit of quantitation (LOQ) are in the accepted range below the lower limit of Beer's law range (Table 3).

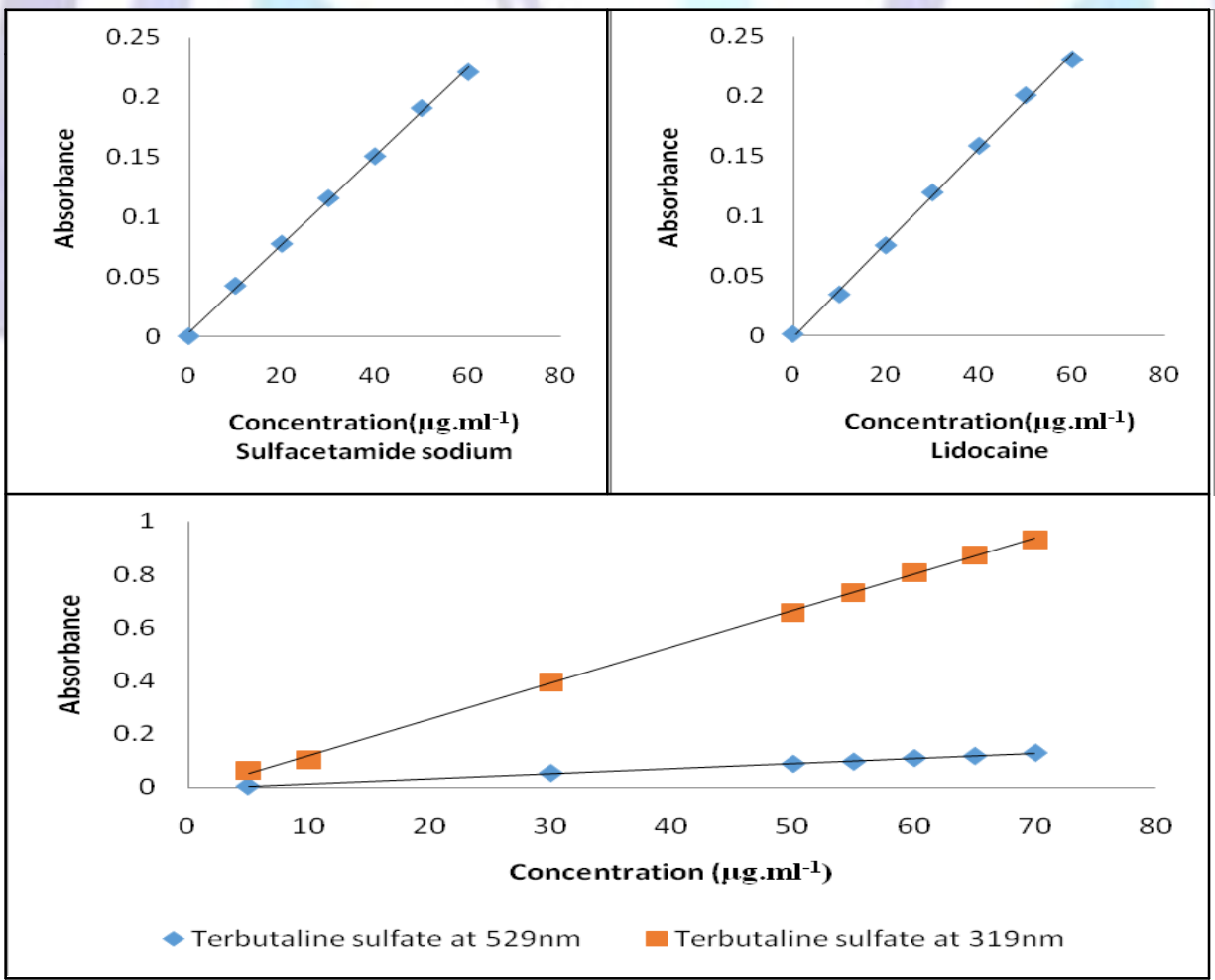

Table (2) Characteristics parameters for complexes of the studied drugs 


\begin{tabular}{|c|c|c|c|c|}
\hline Parameter & $\begin{array}{l}\text { Sulfacetamide } \\
\text { sodium }\end{array}$ & Lidocaine & $\begin{array}{c}\text { Terbutaline } \\
\text { sulfate at } 529 \\
\text { nm }\end{array}$ & $\begin{array}{c}\text { Terbutaline } \\
\text { sulfate at } 319 \\
\mathrm{~nm}\end{array}$ \\
\hline $\begin{array}{l}\text { Linearity range } \\
\left(\mu \mathrm{g} \cdot \mathrm{ml}^{-1}\right)\end{array}$ & $10-60$ & $10-60$ & $5-70$ & $5-70$ \\
\hline $\begin{array}{c}\text { Molar absorptivity } \\
\left(\text { L. } \mathrm{mol}^{-1} . \mathrm{cm}^{-1}\right)\end{array}$ & 940.7 & 913.8 & 987.7 & 7407.5 \\
\hline $\begin{array}{l}\text { Sandell's Sensitivity } \\
\qquad\left(\mu \mathrm{g} \cdot \mathrm{cm}^{-2}\right)\end{array}$ & 0.27 & 0.25 & 0.55 & 0.07 \\
\hline $\begin{array}{c}\text { LOD } \\
\left(\mu \mathrm{g} \cdot \mathrm{ml}^{-1}\right)\end{array}$ & 0.97 & 1.35 & 1.89 & 1.03 \\
\hline $\begin{array}{c}\mathrm{LOQ} \\
\left(\mu \mathrm{g} \cdot \mathrm{ml}^{-1}\right)\end{array}$ & 2.96 & 4.11 & 5.73 & 3.14 \\
\hline $\begin{array}{l}\text { Average recovery* } \\
(\%)\end{array}$ & 101.25 & 101.42 & 100.34 & 100.20 \\
\hline $\mathrm{RSD}^{*}$ & $\leq 3.11$ & $\leq 3.44$ & $\leq 3.51$ & $\leq 0.69$ \\
\hline Slope & 0.0037 & 0.0039 & 0,0018 & 0.0135 \\
\hline Intercept & 0.0042 & 0.0004 & 0.0005 & 0.0101 \\
\hline $\begin{array}{l}\text { Correlation } \\
\text { coefficient }\end{array}$ & 0.9989 & 0.9982 & 0.9985 & 0.9992 \\
\hline
\end{tabular}

\section{Selectivity}

In order to evaluate the selectivity of the proposed method for the analysis of pharmaceutical formulations, the effect of the presence of common excipients was tested for possible interference in the assay by placebo and synthetic mixture analyses.

Three different placebo contents, as described in Table 3, were prepared by mixing amounts of pure sulfacetamide sodium, terbutaline sulfate and lidocaine separately with different amounts of starch, acacia, lactose, methylpraben (MHB) and ethylparben (BHB). Mixed together and dissolved in $30 \mathrm{ml}$ absolute ethanol (except for terbutaline sulfate dissolved in $20 \mathrm{ml}$ methanol). The contents are shaken well for $20 \mathrm{~min}$ and filtered through filter paper and the filtrate is completed to $50 \mathrm{ml}$ ethanol absolute in a volumetric flask. An amount equivalent to $50 \mu \mathrm{g} \cdot \mathrm{ml}^{-1}$ of each drug is measured under the optimum conditions by following the recommended procedure.

The analysis of synthetic mixture solution prepared as described earlier yielded percent recoveries which ranged between 95.34 and 101.58 for three different placebo (Table 4). The results of this study showed that the inactive ingredients did not interfere in the assay indicating the high selectivity of the proposed method.

Table (3): Placebo contents of exciepients

\begin{tabular}{|c|c|c|c|c|c|}
\hline \multirow{2}{*}{ Placebo no. } & \multicolumn{5}{|c|}{ Content (mg) } \\
\cline { 2 - 6 } & starch & acacia & lactose & methylpraben & ethylparben \\
\hline 1 & 10 & 15 & 10 & 10 & 10 \\
\hline 2 & 15 & 20 & 15 & 15 & 20 \\
\hline 3 & 5 & 10 & 5 & 20 & 15 \\
\hline
\end{tabular}


Table (4): Effect of exciepients on the determination of $50 \mu \mathrm{g} \cdot \mathrm{ml}^{-1}$ of drugs.

\begin{tabular}{|c|c|c|c|c|}
\hline \multirow{2}{*}{ No. of placebo } & \multicolumn{3}{|c|}{ Recovery\% } \\
\cline { 2 - 4 } & \multirow{2}{*}{$\begin{array}{c}\text { Sulfacetamide } \\
\text { sodium }\end{array}$} & \multicolumn{2}{|c|}{ Terbutaline sulfate } & \multirow{2}{*}{ Lidocaine } \\
\cline { 2 - 4 } & 101.5791 & 98.6111 & 99.2908 & \multirow{2}{*}{96.1966} \\
\hline 1 & 99.1872 & 100.2541 & 100.8511 & \multirow{2}{*}{95.3419} \\
\hline 2 & 100.1953 & 100.4717 & 95.3192 & 96.1966 \\
\hline 3 & & & & \\
\hline
\end{tabular}

\section{Composition and stability constant $\left(\mathrm{K}_{\mathrm{st}}\right)$ of the complexes}

The compositions of all charge transfer complexes are found to be 1:1 by both Job's and mole ratio methods. The results are shown in the Figures (5).

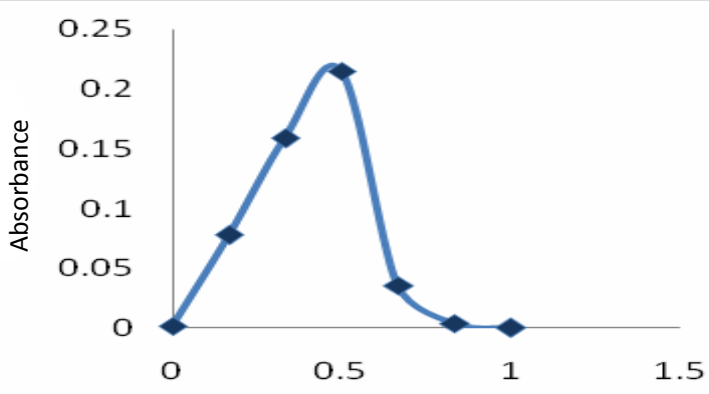

[Sulfacetamide sod.]/[Sulfacetamide sod.]+[p-CA]

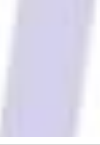

0.09 $\underbrace{0.08}_{\text {ஸ્ }} 0.07$ กั้ 0.05 ัั 0.04 ผั0.03 ष्. 0.02 0.01 $\mathrm{O}$ $\begin{array}{llll}0 & 0.5 & 1 & 1.5\end{array}$ [Terbutaline sulfate]/[Terbutaline
[Sulfacetamide sod.]/[p-CA]
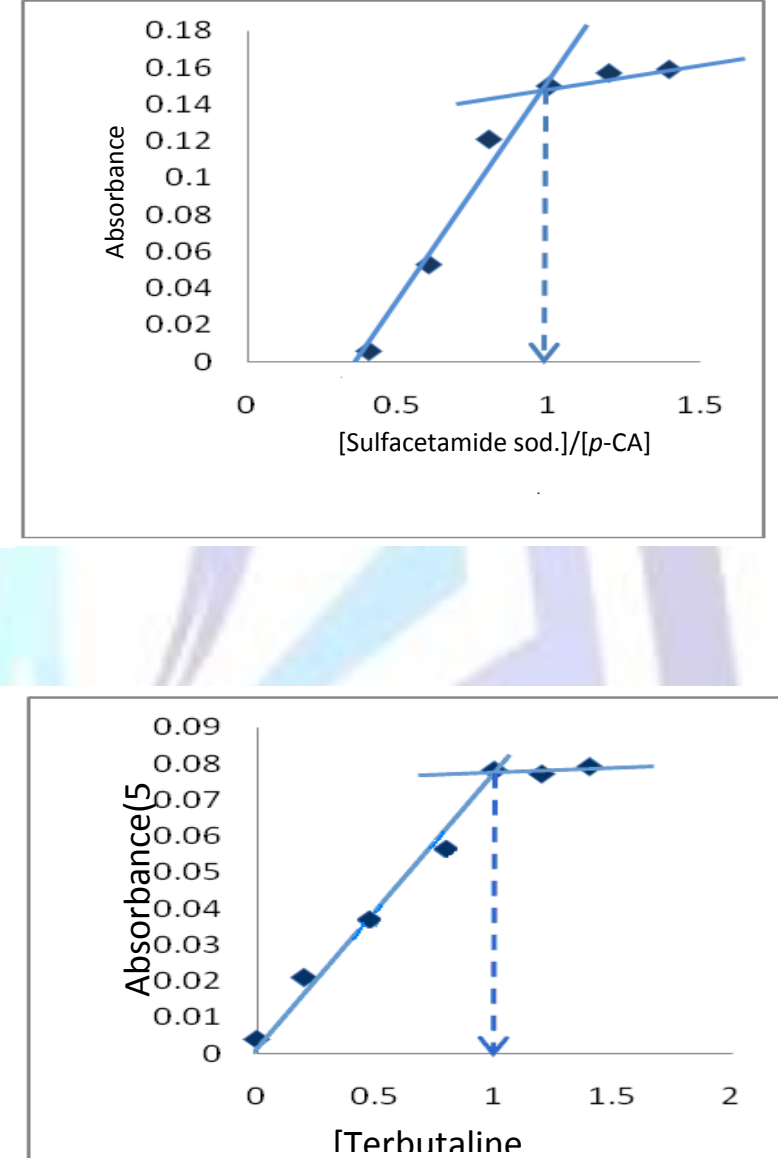

「Terbutaline 

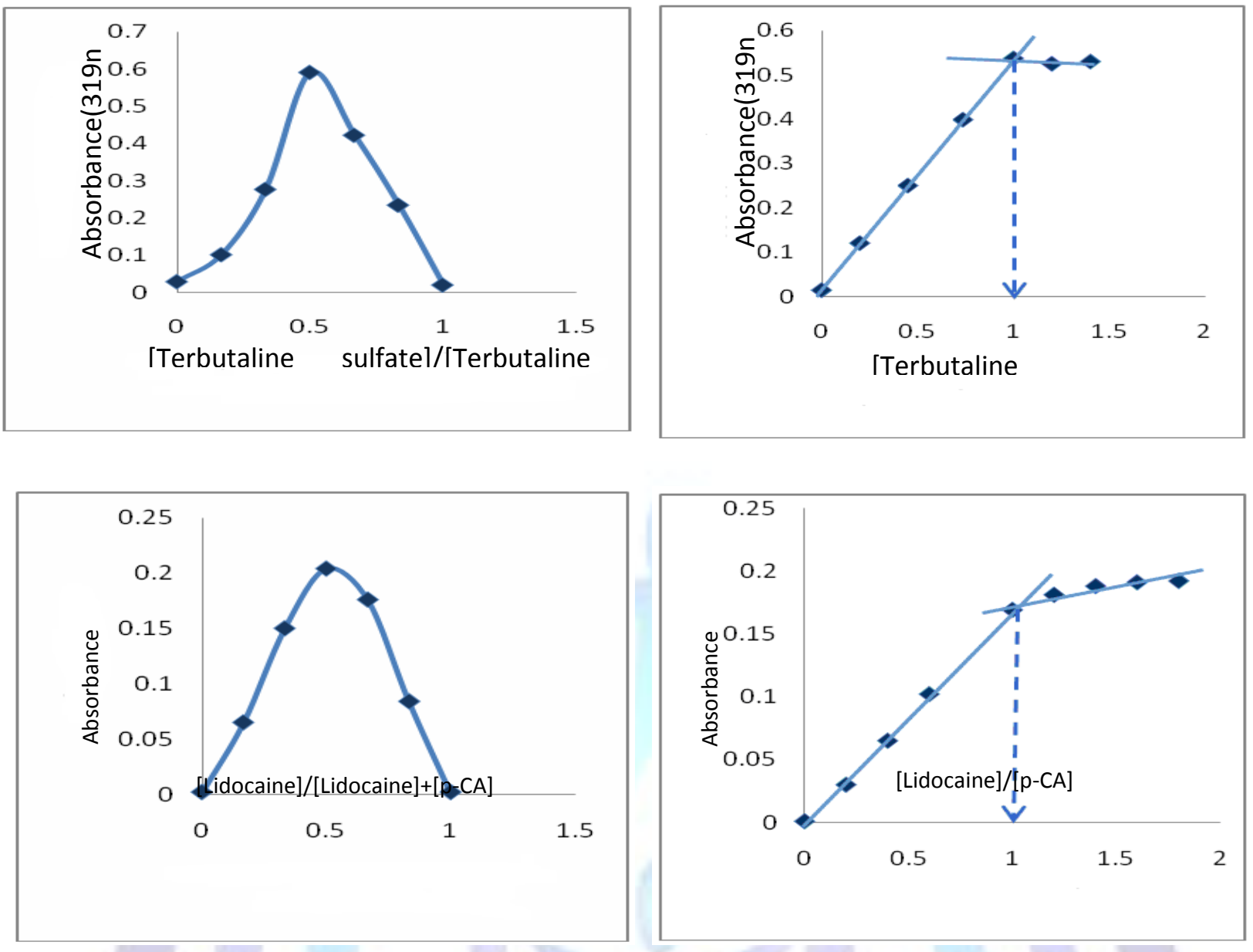

Fig. 5: Continuous variation and mole ratio plots of drug- $p$-CA complexes

The average stability constant $\left(\mathrm{K}_{\mathrm{st}}\right)$ in $\left(\mathrm{L} . \mathrm{Mol}^{-1}\right)$ for three different concentrations of each drug is $4.3 \times 10^{6}$ for sulfacetamide sodium, $3.2 \times 10^{6}$ for lidocaine, $2.1 \times 10^{6}$ for terbutaline sulfate at $529 \mathrm{~nm}$ and $4.8 \times 10^{5}$ for terbutaline sulfate at $319 \mathrm{~nm}$ indicating the high stability of complexes.

\section{Reaction mechanism}

The interaction of the studied drugs with $p-C A$ in organic solvent, was a charge-transfer complexation reaction between the present amino group in the drugs as $\mathrm{n}$-donor and $p-C A$ as $\pi$-acceptor, followed by the formation of a radical anion. Complete electron transfer from the donor to the acceptor moiety took place with the formation of intensely colored radical ions (scheme 2) 


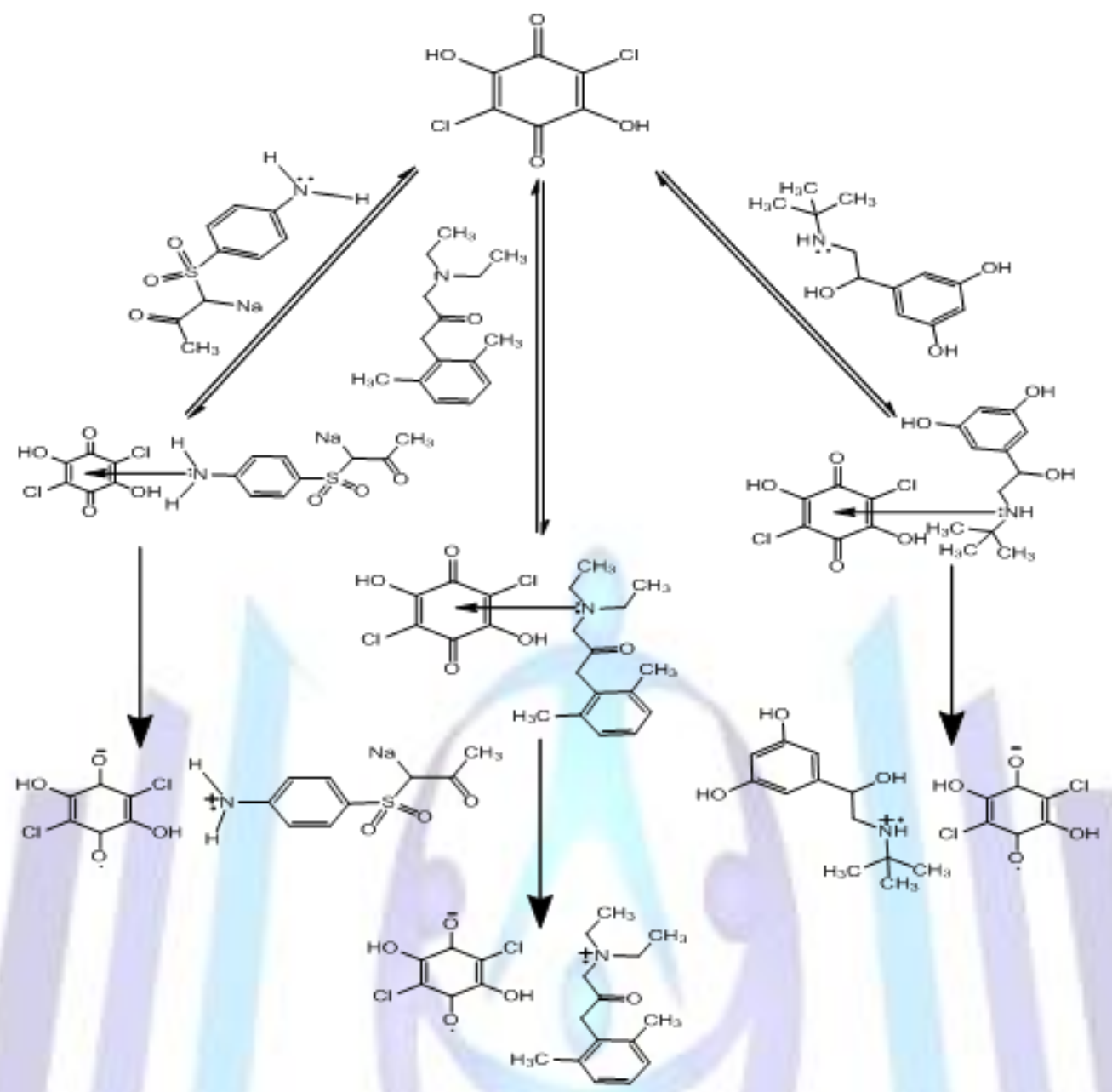

Scheme 2: Proposed mechanisms of charge transfer complex formation reaction for assay of the drugs by $p$-CA.

\section{Application of the developed method on the pharmaceutical formulations}

The proposed method was applied for estimation of the studied drugs in pharmaceutical formulations, three concentrations for each drug was used. The obtained average recovery\% ranges between 95.05 and 97.99 indicates that the method is accurate and the RSD\% is $\leq 4.75$ indicate the method is precise, (Table 5). The method was compared with the British Pharmacopeia [31] procedures, which are depended upon the potentiometric titration. The obtained results were compared statistically by a Student's $t$-test for accuracy and a variance ratio $F$-test for precision at the $95 \%$ confidence level with six degrees of freedom, as cited in Table 5. The results showed that the experimental $t$-test and $F$ test were less than the theoretical value ( $t=2.45, F=6.39$ ), indicating that there was no significant difference between the proposed method and official method. 
Table (5): Results of Assay of Assay of drug in pharmaceutical preparations using the proposed method.

\begin{tabular}{|c|c|c|c|c|c|c|}
\hline $\begin{array}{c}\text { Pharmaceutical } \\
\text { preparation }\end{array}$ & $\begin{array}{l}\text { Certified } \\
\text { Value }\end{array}$ & $\begin{array}{l}\text { Amount } \\
\text { present } \\
\left(\mu \mathrm{g} \cdot \mathrm{ml}^{-1}\right)\end{array}$ & $\begin{array}{l}\text { Drug content } \\
\text { found }^{*}\end{array}$ & $\begin{array}{c}\text { Recovery } \\
(\%)\end{array}$ & $\begin{array}{c}\text { Average } \\
\text { recovery } \\
(\%)\end{array}$ & RSD\% \\
\hline \multirow{3}{*}{$\begin{array}{l}\text { Sulfacetamide } \\
\text { sodium eye drop }\end{array}$} & \multirow{3}{*}{$100 \mathrm{mg} \cdot \mathrm{ml}^{-1}$} & 10 & 9.270 & 92.703 & \multirow{3}{*}{95.25} & 1.49 \\
\hline & & 30 & 28.392 & 94.64 & & 0.88 \\
\hline & & 50 & 49.200 & 98.405 & & 0.52 \\
\hline \multirow{3}{*}{$\begin{array}{c}\text { Terbutaline sulfate } \\
\text { tablet } \\
\text { (at } 529 \mathrm{~nm})\end{array}$} & \multirow{3}{*}{$5 \mathrm{mg}$} & 20 & 20.556 & 102.778 & \multirow{3}{*}{96.22} & 4.75 \\
\hline & & 40 & 37.5 & 93.75 & & 2.73 \\
\hline & & 60 & 55.278 & 92.13 & & 1.84 \\
\hline \multirow{3}{*}{$\begin{array}{c}\text { Terbutaline sulfate } \\
\text { tablet } \\
\text { (at } 319 \mathrm{~nm})\end{array}$} & \multirow{3}{*}{$5 \mathrm{mg}$} & 20 & 20.03 & 100.13 & \multirow{3}{*}{95.05} & 0.19 \\
\hline & & 40 & 36.026 & 90.065 & & 0.27 \\
\hline & & 60 & 56.97 & 94.951 & & 0.32 \\
\hline \multirow{3}{*}{ Lidocaine gel } & \multirow{3}{*}{$2 \%$} & 10 & 9.4 & 93.974 & \multirow{3}{*}{97.99} & 4.14 \\
\hline & & 30 & 30.17 & 100.556 & & 1.28 \\
\hline & & 50 & 49.72 & 99.436 & & 1.82 \\
\hline
\end{tabular}

Average of four determinations

Table (6): Comparison of the proposed method with official method:

\begin{tabular}{|c|c|c|c|c|c|}
\hline \multirow{2}{*}{ Drug determined } & \multirow{2}{*}{$\begin{array}{l}\text { Pharmaceutical } \\
\text { formulation }\end{array}$} & \multicolumn{2}{|c|}{ Recovery(\%) ${ }^{*}$} & \multirow{2}{*}{$t_{\text {exp. }}$} & \multirow{2}{*}{$F_{\text {exp. }}$} \\
\hline & & $\begin{array}{l}\text { Present } \\
\text { method }\end{array}$ & $\begin{array}{l}\text { Standard } \\
\text { method }\end{array}$ & & \\
\hline Sulfacetamide sodium & $\begin{array}{c}\text { Apisulfa-10 Sterile } \\
\text { Eye Drops }\end{array}$ & 95.249 & 99.44 & 1.806 & 1.677 \\
\hline $\begin{array}{c}\text { Terbutaline sulfate } \\
\text { at } 529 \mathrm{~nm}\end{array}$ & Asmanol tablets & 96.219 & 99.5 & 0.81 & 4.476 \\
\hline $\begin{array}{c}\text { Terbutaline sulfate at } \\
319 \mathrm{~nm}\end{array}$ & Asmanol tablets & 95.049 & 99.5 & 1.6 & 4.07 \\
\hline Lidocaine & xylogel & 97.986 & 94.3 & 1.67 & 2.57 \\
\hline
\end{tabular}

*Average for six determinations

\section{Conclusion}

The proposed spectrophotometric method has been developed for the determination of microgram amounts of 10$60 \mu \mathrm{g} \cdot \mathrm{ml}^{-1}$ for each of sulfacetamide sodium and lidocaine and 5-70 $\mu \mathrm{g} \cdot \mathrm{ml}^{-1}$ for terbutaline sulfate with a good accuracy and precision. The statistical analyses show that the data from the proposed method are in a good agreement with those of the official method. The method does not require stringent conditions nor any specific reagent or buffer solution and the color is stable more than 24 hours. The proposed method has been applied successfully for the assay of the pharmaceutical formulations of sulfacetamide sodium

(eye drops), terbutaline sulfate (tablets) and lidocaine (gel). 


\section{REFERENCES}

[1] Othman, N. S. and Kadder, R. M.. 2006. Application of trifluoperazine hydrochloride as a chromogenic reagent for spectrophotometric determination of sulfacetamide sodium- application to ophthalmic preparations, J. Raf. Sci,17(4), 92-103.

[2] Betageri, V. S. Kulkarni, R. M., Shivaprasad K. H. and Shivshankar, L. M. 2011. Kinetic spectrophotometric determination of sulpha drugs in pharmaceutical formulations. Der. Pharma. Chemica. 3(2), 227-235.

[3] http://www.sigmaaldrich.com/catalog/product/sigma/ S8647? lang= en \& region=IQ.

[4] Chanda, R., Nath L. K. and Mahapatra, S. 2009. Formulation development of oral mucoadhesive coated terbutaline sulfate tablets using some natural materials extracted from edible fruits available in India. Iranian J. Pharm. Sci. 5(1), 3-12.

[5] Senthilraja, M. and Giriraj, P. 2011. Reverse phase HPLC method for the simultaneous estimation of terbutaline sulfate, bromhexine $\mathrm{HCl}$ and guaifenesin in cough syrup. Asian. J. Pharm. Clin. Res, 4(2), $13-15$.

[6] Singhall, P., Jadoun, G. S., Sinha, M. and Saraf, S. A. 2010. Formulation and evaluation of buccal patches of terbutaline sulfate. Int. J. Res. Pharm. Sci. 1(4), 440-449.

[7] Chanda, R., Roy, A. Bahadurb, S., Saha, S., Das S. and Choudhury,A. 2010. Formulation of terbutaline sulfate mucoadhesive sustained release oral tablets from natural materials and in vitro-in vivo evaluation. Asian J. Pharm. Sci. 5 (4), 168-174.

[8] Malenović, A., Ivanović, D., Medenica, M. and Jančić, B. 2004. Application of the response surface methodology for RP-HPLC analysis of lidocaine and cetrimoniunm bromide Acta Chim. Slov. 51, 559-566.

[9] Mallu, U., R. Reddy, K. H., Bobbarala V. and Penumajij, S. 2011. Determination of beclomethasone dipropionate, clotrimazole chloramphenicol and lidocaine in pharmaceutical formulations using a novel RP- HPLC method. Int. J. Pharm.\& Bio. Sci. 2(3), 1-10.

[10] Medicine Net.com, http://www.medicinenet.com/lidocaine_viscous/article.htm.

[11] Kang, L., Jun H.W. and McCall J.W. 1999. HPLC assay of Lidocaine in plasma with solid phase extraction and UV detection. J. Pharm. Biomed. Anal. 19,737-45.

[12] Kim, K. H. et al. 2000. Determination of terbutaline enantiomers in human plasma by coupled achiral-chiral high performance liquid chromatography. Arch. Pharm. Res. 23, 5, 441-445.

[13] Penner, M. H. 1975. Assay of sulfacetamide sodium ophthalmic solutions by high-pressure liquid chromatography. J. Pharm. Sci., 64, 6, 1017-1019.

[14] Msagati, T. A. M. and Ngila, J. C. 2002. Voltammetric detection of sulfonamides at a poly(3-methylthiophene) electrode. Talanta, 58, 605-610.

[15] Tan, G. et al. 2012. Determination of lidocaine based on electrocatalysis of a chemically modified electrode. Turk J Chem. 36, $593-600$.

[16] Yilmaz, N. et al. 1998. Determination of terbutaline based on oxidation by voltammetry. J. Pharm. Biomed. Anal. 17, 2, 349-355

[17] Jacobsson, S.E. et al.1980. Determination of terbutaline in plasma by gas chromatography chemical ionization mass spectrometry. Biomed. Mass Spectr. 7,265-8.

[18] Arimoto, H., Shiomi K. and Fujii,T. 1991. Determination of lidocaine in human serum by capillary gas chromatography with surface ionization detection. J. of High Resolution Chromatography. 14, 10, 672-675.

[19] Pena, M. S. et al. 1992. Spectrofluorimetric determination of sulphonamides in pharmaceutical compounds and foods. J. Pharm. Biomed. Anal. 10, 805-808.

[20] Nagaraja, P. et al. 2007. A sensitive spectrophotometric method for the determination of sulfonamides in pharmaceutical preparations. Acta Pharm. 57, 333-342.

[21] Nagaraja, P. et al. 2002. Iminodibenzyl as novel coupling agent for the spectrophotometric determination of sulfonamide derivatives. Eur. J. Pharm. Biopharm. 53, p. 187 - 192.

[22] Upadhyay, K. Asthana, A. and Tiwari, N. 2012. Solid phase extractive spectrophotometric determination of some sulpha drugs. Asia. J. Pharm. Clin. Res., 5, 222 - 226.

[23] Nagaraja, P. et al. 2003. 3-Aminophenol as a novel coupling agent for the spectrophotometric determination of sulfonamide derivatives. Farmaco. 58,1295 - 1300.

[24] Smith, A. A. Manavalan, R. and Sridhar, K. 2010. Spectrophotometric estimation of terbutaline sulfate in pharmaceutical dosage forms. Int. Res. J. Pharm. 1, $213-219$. 
[25] Li-qing, Z. et al. 2010. Spectrophotometric determination of terbutaline using $\mathrm{K}_{3}\left[\mathrm{Fe}(\mathrm{CN})_{6}\right]-\mathrm{FeCl}_{3}$. Huaxue Yanjiu Yingyong. 22, 961-964.

[26] Bhatt, K. K., Shah S. A. and Pandya, S.S. 1999. Spectrophotometric determination of terbutaline sulfate in bluk and dosage forms. $6,318-319$

[27] Zong-huil, Q., Rong T. and Wu-hongl, H. 2008. Spectrophotometric method for determination of lidocaine hydrochloride and its analytical applications. J. Henan Normal University (Natural Science), 1.

[28] Zonghni, Q. S. Guangming, T. Rony and P. Lijun, 2007. Determination of the content of lidocaine hydrochloride in different medium by spectrophotometric method. China Pharm. 34.

[29] Putta, M. et al.2013. Spectrophotometric determination of lidocaine in bulk and pharmaceutical formulations. Pharm. Analysis and Quality Assurance WWW. Inventi. In/Articale/ppaqa/573/12.aspx.

[30] Zhao, F. L. et al. 2005. Spectrophotometric study on the interaction of water with chloranilic acid and its analytical application. Chin. Chem. Lett. 16(7), p. 931-934.

[31] British pharmacopoeia. (2007), CD Rom.

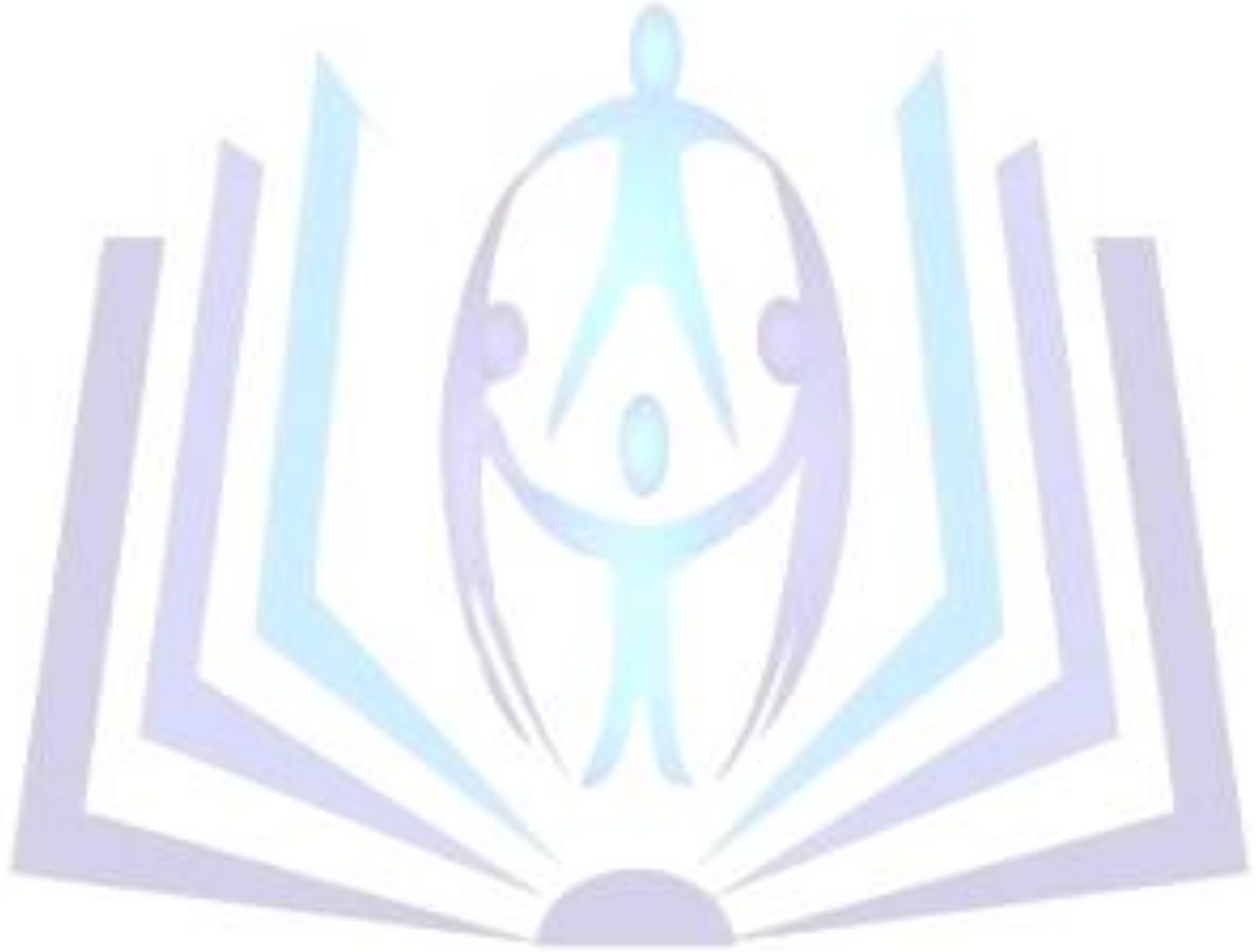

